\title{
The Participation and Transparency in Regional Budgeting of South Timor Tengah District in 2017
}

\author{
Marthinus P. David* Ajis S. Adang Djaha Petrus de Rozari \\ Graduate Program of Administrative Science, Universitas Nusa Cendana Kupang, Nusa Tenggara Timur, \\ Indonesia
}

\begin{abstract}
This research analyzed and explained: (1) The transparency in the Regional Budget planning based on the Regional Budget planning mechanism in 2017 in TTS; (2) The degree of society participation through the Regional Budgeting mechanism in 2017 in TTS; (3) Supporting and inhibiting factors toward the transparency and participation of the society in the planning of Regional Budget in 2017 in TTS. This research employed a qualitative research approach in the form of case study which was rather instrumental (DEnzin and Lincoln, 2009). This research was conducted in the South Timor Tengah District, including six villages in five sub-districts: Tune Village and Tutem Village in Tobu Subdistrict, Abi Village in Oenino Subdistrict, Baus Vilalge in Boking Subdistrict, O'of Village in Kuatnana subdistrict and Hane Village in Batu Putih Subdistrict. Those locations were purposively determined. The focuses of this research were on two aspects: (1) The transparency in Regional Budget planning (2) Participation form the society in the Regional Budget planning. Research data were collected through several techniques including documentary research, interviews and observation (Cresswell, 2002; Denzin and Lincoln, 2009; Yin, 1996).

The results of this research showed that out of the 14 stages of the Regional Budget planning in the South Timor Tengah, Transparency aspect was involved in the first stage (Preparation of Local Government Work Plans), the eighth stage (Collecting agreements with the District Regional House of People's Representatives or DPRD and regional heads), the 13th stage (Establishment of Regional Regulation on Regional Budget based on the evaluation results) and 14th stage (Submission of Regional Regulation on Regional Budget and Regional Head Regulation concerning the explanation of Regional Budget for the Minister of Home Affairs / Governor). In the first stage, the society was given the chance to participate and give their opinions. Meanwhile, the transparency in stage 8 , 13, and 14 limited the society to only being able to access information without being given the chance to give their opinions. Consequently, the level of transparency was foudn relatively low (28.57\%). Transparency mechanisms were still limited within the Development Planning Consultation (Musrenbang) at the sub-village, village and subdistrict levels, and during the recess of DPRD members.
\end{abstract}

Keywords: Participation, Transparency, Budget, Region

DOI: $10.7176 /$ RHSS/9-20-01

Publication date:October $31^{\text {st }} 2019$

\section{INTRODUCTION}

Transparency is a major topic within accountability studies. Dwivedi (1988) stated that accountability is the foundation of any government process. The effectiveness of the process depends on how government use the authority to make their legal and constitutional ways carrying out their responsibilities. Explaining the government responsibility the public depends on government's ability in providing open information for the public (transparency) to allow the public easily access it (Dwivedi, 1988). Easy access of information related to government administration is expected to engage the public to actively participate in the administration process.

There are two principles of a good governance: good governance that is participatory and transparent. Therefore, the government must provide sufficient space for people to participate in the administration process, including the preparation of the Regional Budget (APBD). The space for public participation in budgeting can be enhanced if government administrators are willing to be open (transparent) throughout the drafting process.

The application of those two principles have been analyzed in some research to provide information about the problems regarding public participation and transparency in the administration of regional government, especially in the formulation of public policies on local budgets (APBD). The South Timor Tengah (TTS) government has applied the participatory budgeting system. This policy provides space for the TTS community to participate in the budgeting process by expressing their opinions regarding the utilization of local budgets.

In accordance with the prevailing laws and regulations, the public can participate in development planning meetings (Musrenbang), recess period for DPRD members, DPRD open meetings, DPRD members' work visits, public consultations, mass media, and even demonstrations. This mechanism is expected to give the community broader spaces to convey their ideas, while at the same time overseeing the use of local budgets. Hence, regional problems can be well-addressed.

This study aimed to analyze and explain: (1) Transparency of Regional Budget preparation through the mechanism of Regional Budget preparation in 2017 in TTS; (2) The degree of community participation through 
the mechanism of preparing the Regional Budget in 2017 in TTS; (3) Supporting and inhibiting factors to the transparency and community participation in the preparation of the 2017 Regional Budget in TTS.

It is expected that this research provide valuable information and benefits to a number of parties, including: (1) Regional Government to give more emphasis on the principles of participatory and transparent government in order to make implementation of regional government, particularly in preparing regional budgets (2) The Regional People's Representative Council who are expected to express people's ideas by taking into account the principle of transparency in the preparation of the Regional Budget. This research also analyzed the factors that support and inhibit the community participation and transparency in the preparation of the Regional Budget to be wellanticipated. (3) The community is expected to learn from the 2017 Regional Budget preparation to enhance their participation in order to direct the use of the regional budget (APBD) to match the needs of the TTS community. (4) Other researchers are encouraged to conduct further research using a quantitative approach to examine the relationship between community participation and transparency through factors that have been qualitatively identified and analyzed in this cross-site / case analysis.

\section{LITERATURE REVIEW}

\section{TRANSPARENCY IN BUDGETING}

Evaluating the transparency applied in previous bureaucratic systems is challenging, since transparency is interpreted as the openness of bureaucracy for any activities carried out to the public and the availability of information about policies, the design and implementation processes, and the outcome which are not the main aspects in Weber's ideal type of bureaucracy. On the contrary, Weber emphasizes the importance of flow of information (reporting and accountability) internally both vertically (between superiors) and horizontally (between bureaucrats at the same office or class level) through the principle of hierarchy in the bureaucracy (in Etziony and Halevy, 2011: 42-44). Bureaucracy is basically a close-ended organization that applies the principles of esoteric or confidentiality (Denhard and Denhard, 2007).

Criticisms toward Max Weber's rational bureaucracy were raised by some experts including Merton who criticized the principle of the Weberian-style bureaucratic hierarchy which according to hierarchy could cause less-transparent bureaucracy (secretive or esoteric). Moreover, the bureaucratic structure of many levels (hierarchy) formed within similar work conditions allows officials to develop group solidarity that can lead to rejection of various necessary changes. In this case, the bureaucracy will not welcome changes that occur in the external environment either through rejection or closing the opportunity for the public to participate and control every bureaucratic activity (in Djaha, 2012).

Transparency which is interpreted as a form of information disclosure to the public is one of important issues in realizing and guaranteeing accountable public administration system. Haylar said that to ensure accountability in the administration of the government system, transparency should be implemented in 5 (five) major aspects, namely (1) discussion in parliament, (2) public information services, (3) information disclosure, (4) public hearings, (5) ) annual report. Transparency can actually be further explored in the context ofexternal accountability development within public administration studies (Kumorotomo, 2008: 8).

Bureaucratic transparency can also be traced from the shift of public administration perspectives from the Old Public Administration (OPA), New Public Management (NPM), and New Public Service (NPS). Accountability is regarded equal to transparency, in which accountability requires the publishing of reports to external parties or independent organizations (legislators, auditors, public) (Peters in Haryatmoko, 2011: 109). The development of accountability can be used to explain the development of transparency through three perspectives First, through the public administration, Old Public Administration (OPA) which holds that public administrators are solely responsible directly to political officials. This means that public administrators are only open (transparent) to public officials. Second, the New Public Management (NPM) emphasizes on giving administrators broader space as entrepreneurs where public managers are being responsible in terms of efficiency, cost effectiveness, and level of responsiveness to market pressures. Third, the New Public Service (NPS) sees that accountability in the public sector must be able and must serve the public according to the public interest and object to the market-based efficiency or standards. This view regards the citizens as the main actors in the New Public Service study within the field of public administration studies (Derhardt. And Denhart, 2007).

Transparency is also one of the 8 (eight) principles of good governance. Governance itself is the sixth paradigm of public administration (Henry, 2004). Thus, transparency which is one of the important principles of good governance is seen as one of the important concepts in the study of public administration.

\section{FACTORS GUARANTEEING THE TRANSPARENCY}

According to Oliver (2004) four key elements should be implemented for a fully-transparent organization. (1) Culture dedicated to openness and transparency commitments from the most senior leaders in the organization; (2) Programs and processes that stimulate and guarantee openness at all levels, rewards for transparency and penalties if the administration deceives, distorts facts, and cheats; (3) Well-trained workers, managers and administrators at 
all organization levels with strong wisdom, integrity, confidence and security to do and say right things. Able to acknowledge and make good actions when the organization or individual acts improperly; (4) Providing proactive communication channels for important stakeholders of the organization.

Those four elements can be realized through the implementation of four principles as explained by Oliver (2004) including (1) Leadership commitment. Organizational leaders are bounded by the principles of transparency. They instill commitment in communicating with stakeholders, collecting information within certain metric system. This commitment is demonstrated by the standards by which senior leadership engages, documents and communication in governance processes, metrics, discussions, performance, as well as continuous enforcement, transparency and ethical guidelines; (2) Formal processes. Transparency requires frequent, adequate and accurate information. The responsibility for compiling and reporting information metrics should be wellanticipated. Each related metric contains a reporting mechanism or process; (3) Training program. The commitment to transparency among top management is enhanced through comprehensive training programs that communicate this commitment and demonstrate the way to achieve it, including special channels for reporting violations. Managers are taught how to collect, analyze, and report coded information, which is the information that strips of particular industry, organization, or profession jargons in accurate and easy to be understood by nontechnical audiences. Employees show how to foresee the future need for impending transparency and familiarize themselves with the changing market demands. The training not only teaches documentation and reporting competencies, but it also develops critical thinking skill and decision-making skill, while at the same time stimulates the understanding and commitment to transparency and ethical behavior; (4) Adequate communication with stakeholders. Transparency does not only allow stakeholders to look iinto the organization. Transparency requires active disclosure, periodical communication of essential information, fast, easy and inexpensive means of obtaining feedbacks. Transparent communication with stakeholders is not only limited to traditional figures such as financial data, consumer or public statistics, and operational metrics, but it also deals with accurate and comprehensible discussion about stakeholder. This is the aspect that determiens between organizational success and failure. Frequent communication with essential stakeholders. Feedback from stakeholders (employees, constituents, community leaders) tells the organization what has been done properly and what aspects that should be improved.

\section{Community Participation in Regional Governance}

Majid Rahnema in Muluk (2007: 45-46) stated that participation consists of transitive participation and intransitive participation. Transitive participation is oriented towards specific goals. Conversely, intransitive participation occurs when certain subjects participate without having any clear purpose. Participation can also be classified into manipulative or spontaneous participation. Manipulative participation refers to participation where participants are directed to participate by forces outside their control. Uma Lele in Rahnema in by Muluk (2007: 47) described participation in the planning and implementation processes, which was then added with the beneficiary participation proposed by Bryant and White and evaluation participation by Griesgraber and Gunter which takes into account community autonomy and independence.

Muluk (2007: 51) explained that community participation includes participation in the process of planning, implementing, evaluating, and obtaining developmental benefits by considering the community autonomy and independence. Participation involves individuals, and groups, both ad hoc and permanent stakeholders. Participation begins from the policy making process, and implementation process that allows public to have a control.

Muluk (2007: 56) also added that community participation in regional government refers to the direct, voluntarily, independent involvement of the community in the planning and implementation of regional policies within the context regional autonomy implementation.

Sherry R. Arstein (in Muluk, 2007: 59) explained that community participation has different degrees between individuals, groups or community. Arnstein introduced three degrees of participation namely (1) non-participation (manipulative participation), (2) signs of participation (participation in the form of providing information, consultation, or reassurance), and (3) public authority (in the form of delegated power, public control). The degree of participation is shown in Figure 1.

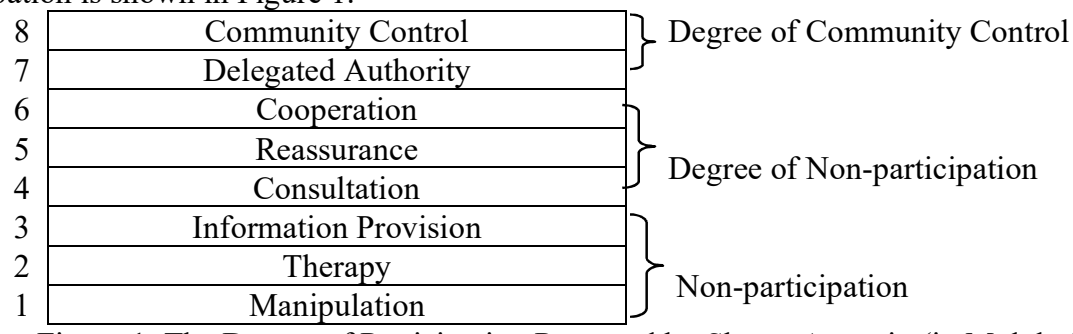

Figure 1. The Degree of Participation Proposed by Sherry Arnstein (in Muluk, 2007:59) 
Arnstein's theory was opposed by Burns, Hambleton, and Hogger who revealed that Arnstein's degree of participation was not suitable within the context of regional government analysis. This objection is sensible as Arnstein's theory is rather suitable to use in the analysis of the relationship between citizens and certain government programs. The degree of participation proposed by Burns, Hambleton, and Hogger is more directed towards empowerment process, which refers to the intended effort made by the government to improve public influence and control in government activities. The degree of participation proposed by Burns, Hambleton and Hogger's participation is shown in Figure 2.

\begin{tabular}{|c|c|c|c|}
\hline \multirow{3}{*}{ 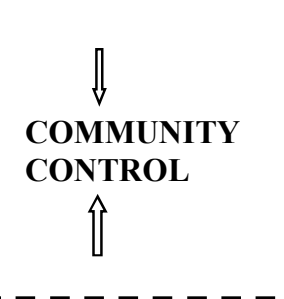 } & Main Characteristics & \multirow[b]{2}{*}{12} & \multirow[b]{2}{*}{ Interdependence } \\
\hline & $\begin{array}{l}\text { Varied forms of democratic control that are } \\
\text { intercorrelated within an enhanced scope. }\end{array}$ & & \\
\hline & $\begin{array}{l}\text { Regional government that concentrates on playing its } \\
\text { strategic role as democratic and pluralistic public space } \\
\text { controller. }\end{array}$ & 11 & Trusted authority \\
\hline & Transformation of role in regional government & 10 & Delegated authority \\
\hline & Support for bottom-up strategy & 9 & Cooperation \\
\hline & & & Limited Decentralization \\
\hline & Management Decentralization & 8 & Decision Making \\
\hline $\begin{array}{l}\text { COMMUNITY } \\
\text { PARTICIPATION }\end{array}$ & Localization of performance-based service & 7 & Effective advisory board \\
\hline$\Lambda$ & $\begin{array}{l}\text { Introduction of direct public involvement in decision } \\
\text { making process }\end{array}$ & 6 & True consultation ${ }^{6}$ \\
\hline & $\begin{array}{l}\text { Development of language, method, trust and } \\
\text { assumption to be well-understood by the community. }\end{array}$ & 5 & Quality Information \\
\hline & & 4 & $\overline{\text { Customer Maintenance }}{ }^{4)}$ \\
\hline NON-PARTICIPA & IION & 3 & Poor Information ${ }^{3)}$ \\
\hline & & 2 & Cynical consultation $^{2}$ \\
\hline & & 1 & Community Fraud $^{1)}$ \\
\hline Three Degrees of & ticipa & & egree of participation \\
\hline
\end{tabular}

1) Community fraud often occurs in the form of information distortion, fact covering, and one-way communication.

${ }^{2)}$ treating the procedure as a game. Regional government often asks for public participation only as a formal procedure since the government does not really expect for true participation from the community..

3) indicated by too much information that cannot be accessed by the community to inhibit participation.

4) there is control mechanism and follow up to complaints toward the public service quality. The follow up should be in the form of training that enhances employees' attitude, friendliness, and sincere service. This procedure is often done to only quell public's anger.

5) fulfilling public rights to obtain clear information.

6) engaging the community in decision making process, public hearing, and public discussion. However, the regional government still holds the most dominant role.

6) the community express their ideas/complaints to the members of the house of regional representatives.

7) engagement of limited public control

${ }^{8)}$ Regional government can delegate their authority for the public to give the public stronger bargaining power. Decision making process can be trusted to the users of certain service.

9) Regional government can make good cooperation with local community groups.

10) Regional government may delegate its authority to a group of people in the village to take care of their own necessities. Village organization also has a board of decision maker to execute various policies and control the implementation process as a control mechanism..

11) The community has the authority to lead the implementation of a program in an area based on certain degree of participation after being given the authority from the regional government. Regional government can delegate the management of certain matters for an organization in the form of financial supports or development of various informal supports.

${ }^{12)}$ Regional government and community organization show interdependence. This occurs when community organizations are given the authority to make decision, policy, and financial autonomy.

Figure 2. The Degree of Participation Proposed by Burns, Hambleton, and Hogget in Muluk (2007:69) 
Information distortion, information closure, and one-way communication are signs of non-transparency in the administration of local government, especially in the preparation of local budgets. This condition causes community participation to be at the lowest point. Likewise, local government often asks for public participation only as a formal procedure. When the government is demanded to be open to the public, the government does it, but the information conveyed is rather too dense and cannot be accessed by citizens. Such actions might be forms of both intentional or unintentional actions to hinder participation. Transparent government should make efforts to fulfill the citizens' right to obtain clear and firm information by involving the citizens in decision making process, public meeting, and public hearing. In fact, local government still plays the most dominant role in decision making process. Therefore, degree of community participation as proposed by experts is expected to map the degree of community participation in the preparation of local budgets through a number of available participation mechanisms.

\section{THE MECHANISM OF PARTICIPATION IN BUDGET PLANNING POLICY}

Participatory budgeting is one of the sub-studies in the study of budget preparation which receives strong attention from practitioners, experts, non-governmental organizations (NGOs) and international institutions (Sukardi, 2009: 69). Participatory budgeting is an innovative public policy making process that allows the citizen to be directly involved in policy making process while overseeing its implementation. The core of participatory budgeting relies on the realization of civil society by empowering and optimally utilizing social capital, human capital, and natural capital in a new governance.

Direct involvement in policy making can be realized into several participation mechanisms. Muluk (2007) stated that there were a number of mechanisms for community participation, namely (a) Development Planning Consultation (Musrenbang), (b) Recess Period, (c) DPRD open meetings, (d) Neighborhood Association (RT) and Community Association $(R W)$; (e) ) Village / Urban Community Empowerment Institutions, (f) online communication port between the community and Regency Government, (g) Visitation of DPRD members, (h) public consultations, (i) alternative mechanisms The following is an explanation of each community participation mechanism.

\section{RESEARCH METHOD}

This research was conducted in the form of instrumental case study using qualitative approach (Denzin and Lincoln, 2009). The research was carried out in South Timor Tengah Regency including six villages in five Subdistricts namely Tune Village and Tutem Village in Tobu District, Abi Village Oenino District, Baus Village in Boking District, O'of Village in Kuatnana District and Hane Village in Batu Putih District. Those locations were purposively selected. There were two major focuses of this research: (1) Transparency in the preparation of Regional Budget. (2) Community participation in preparing the Regional Budget. The data in this research were collected through several techniques including document study, interview and observation (Creswell, 2002; Denzin and Lincoln, 2009; Yin, 1996). Those techniques were used to meet the needs for data regarding regional budget, transparency and community participation. The obtained ate were then qualitatively analyzed using categorization technique, and pattern matching (Yin, 1996), which is referred to as cross-site or cross analysis by Miles and Huberman (1992). The cross-site analysis model employed a matrix which was designed based on the needs of data analysis. To guarantee the quality of data / research results, researchers carried out data recirculation in the form of triangulation of data sources, methods, and literature triangulation (Miles and Huberman, 1992; Creswell, 2002; Denzin and Lincoln, 2009; Yin, 1996).

\section{RESEARCH RESULTS AND DISCUSSIONS}

The results of this research showed that there were 14 stages in the preparation of the Regional Budget. However, only 1 (one) stage was open for public participation. While the other 13 stages did not allow the community to participate. In another word, 13 stages of Regional Budget Planning were not transparent. This result contradicts Haylar's opinion quoted by Kumorotmo in his book entitled Accountability of Public Bureaucracy: Sketches in the Transition Period (2008: 8) in which it is stated that to guarantee accountability in the administration of the government system, transparency is needed in 5 (five) stages, namely (1) discussion in parliament, (2) general information services, (3) information independence, (4) public hearings, (5) annual reports. Budget discussions in parliament need to be open for public to allow public control to prevent ignorance toward public interest. In addition, mass media needs to convey general information related to budget discussions between the DPRD and the Regional Government. Therefore, the public would have the opportunity to access necessary information. It is recommended that before draft of the proposed Regional Budget is discussed by the Regional Government together with the DPRD, public hearings should be first held in order to let the public control the Regional Government and $D P R D$ to account for the Regional Budget draft that is prepared based on community aspirations through musrenbang, the recess period where vision, mission, goals and objectives of the local government were disseminated to be further elaborated in the forms of strategic plans and work plans for all existing OPDs. The 
manifestation of an understanding of the actual meaning of transparency can be reflected in the development of the concept of external accountability within the study of public administration.

The annual budget use report (Regional Budget) published through printed media (local newspapers) every year is seen as a form of transparency of the Regional Government to the public. Accountability is equated with transparency, in which accountability requires open reports to external parties or independent organizations (legislators, auditors, public) through proper publication. This action has been explained by Guy Peters (in Haryatmoko, 2011: 109).

The government has issued the Act Number 14 of 2008 concerning Openness of Public Information where there is a requirement to periodically publish various infromation. Article 9 explains some aspects including the requirement that each Public Agency should publish Public Information regularly including financial statements. This information should be accessible to the public and written in easy-to understand language. Unfortunately, this regulation has not yet been properly implemented TTS District. If only the law is implemented properly, the regional government could be regarded to have applied the third public administration perspective, the New Public Service (NPS). However, as the regulation has not yet been properly implemented, the government was still within the Old Public Administration (OPA), not the NPS. Actually, at the level of rules or norms implementation, the government has been considered within NPS category as explained in Act Number 14 of 2008 in which information that must be openly published has been mapped. Information that must not be disclosed to the public for a number of reasons are outlined in Chapter $\mathrm{V}$ of the Law concerning the exempted information.

Act No. 14 of 2008 guarantees a transparent government in which governance system should be made open for public through clear processes and procedures and ease for citizens to access public information. A high level of transparency stimulates ethical awareness of public services through the dissemination of information which ultimately guarantees performance accountability for individuals and organizations on charge. This idea was originally adapted from John Halligan, Namshin Cho, Cheol H. Oh in an article entitled "Towards Participatory and Transparent Governance" quoted by Djaha (2012).

Act Number 14 of 2008 clearly outlines the open system. Unfortunately, the implementation has not been carried out as it should. This condition showed that (1) The culture dedicated to openness and transparency commitments was not supported by most senior leaders; (2) Programs and processes that stimulate and guarantee openness at all levels, reward transparency and impose penalties should be strictly applied; (3) There is no adequate communication channel to control policy making, including regional budget preparation. The results of the identification of factors that determine transparency are in line with three factors out of the four factors proposed by Oliver, Richard, W (2004).

The preparation of the Regional Budgethas been at least open for public participation, although in the actual practice, only some people used this opportunity.. Different level of participation can occur in society, especially in rural communities. Information disclosure related to the preparation of Regional Budget has an impact on community participation. Some people whose expectation to participate was not properly facilitated tend to have their level of participation lower. However, some other people are not affected by this situation.

The level of community participation is considered to be at the level of non-participation based on a number of indications such as information distortion that is done by covering up the truth, getting the community feel cheated; the community consider public participation as a game because local government often asked citizens to participate, but the participation is merely a form of formal procedure since citizen involvement in government activities is not really expected; Musrenbang was only held in a relatively short period of time in less than a day which was not enough to present all information.

Information distortion, covering up the fact, and one-way communication are signs of non-transparency in the administration of local government, especially the preparation of local budgets. This condition causes the degree of community participation at the lowest point. Likewise, local governments often ask citizens to participate, but only to fulfil the formal procedure. When the government is demanded to be open to the public, the government seems to make it work, but the information conveyed is too much to be accessed by citizens. Actually an open government should facilitate citizens' right to obtain clear and firm information by involving citizens in decision making process, public meeting, and public hearing. However, local government still holds dominant role in the decision making process. The degree of community participation presented in this research is expected to be able to map the degree of community participation in the preparation of local budgets through a number of available participation mechanisms.

After observing data trend from document study and interview, it can be concluded that transparency determines the level of participation. Transparency is seen as openness by the government to accept proposals, opinions from the community in the preparation of the regional budget. Out of 14 stages of regional budget preparation, only one stage was open for public participation. However, careful observation showed that there were no less than 4 - 5 stages can be opened for better public participation. There were 4 stages that can be accessed. One stage allowed the community to give proposals and suggestions, but the other three stages only allowed the public to have access but they could not give agreement. Those three stages included stage 8 (Collecting 
agreements with the DPRD and regional heads), stage 13 (Establishment of Regional Regulations on Regional Budget and Regional Head Regulation on the Explanation of Regional Budgetbased on evaluation results) and stage 14 (Submitting Regional Regulations on Regional Budget and Regional Head Regulation on Spatial Planning to the Minister of Home Affairs /Governor). The stage where the government and the DPRD announce the results of the Regional Budget draft through Regional Government Radio which could only be heard by the public without allowing two-way communication. Thus, information could be accessed only in 4 (four) stages, while the information in 11 other stages could not be accessed. Information publication was also regarded low since the it was annually held.

Based on the results of this research, transparency influences or determines the level of public participation in the preparation of Regional Budget. If the government opens space for the public to participate in the preparation of the Regional Budget, participation will be higher. On the other hand, if the government is not willing to open the space for the public, the participation will be low. The public participation in the context of this research setting was considered in the first level; the participation that tends to be mobilized. This categorization has taken into account the characteristics of non-participation of citizens and the characteristics of citizen participation proposed by Burns, Hambleton, and Hogget (see figure 2). If participation is still on the first level, participation in the form of public pressure is difficult to expect. Based on this explanation, the theoretical (construction) framework has been proposed based on the results of this research as shown in the following figure.

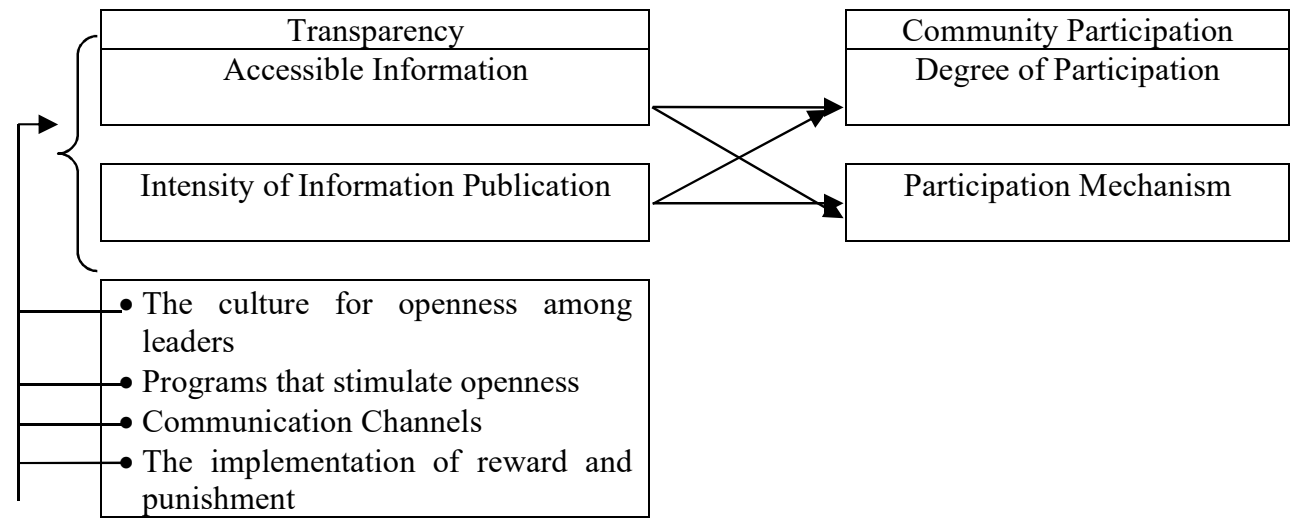

Figure 3. The Framework of Theory of Transparency and Community Participation in Designing Regional Policies

The broader the space for the public to participate in public policy making (Regional Budget preparation), the higher the level of participation (the number of people participating). On the other hand, limited space for public participation will cause lower number of people participating.

The level of openness (transparency) of the government is determined by the willingness and habits (culture) of the leadership and the availability of programs that stimulate openness. Government openness is also supported by mechanisms or communication channels. Transparency can also be enhanced by adequate appreciation for open government, and also strict sanctions for government officials who do not want apply this principle since laws and regulations have made it mandatory.

\section{CONCLUSIONS}

Regarding to the results and discussions of this research, conclusions were drawn as follows.

1. From the 14 stages of Regional Budget Preparation in South Timor Tengah Regency, transparency appeared in the first stage (Preparation of Local Government Work Plans), the eighth stage (Joint agreement between DPRD and regional heads), the 13th stage (Establishment of Regional Regulations regarding Regional Budget and Regulations of Regional Heads concerning the explanation of the Regional Budget based on evaluation results) and the 14th stage (Submission of Regional Regulations on the Regional Budget and Regional Head Regulations concerning the Explanation of the Regional Budget to the Minister of Home Affairs). Transparency in the first stage was realized in the form of opportunities for the community to participate in giving opinions, while transparency in stages 8,13 , and 14 only allowed community can only access information without being able to give opinions. Thus the level of transparency is relatively low (28.57\%). Transparency mechanisms that provide community space for expressing opinion and debate are still limited to the Development Planning Conference (Musrenbang) in sub-village, village, and sub-district levels, and during the recess of DPRD members.

2. Although the space has been opened (there is transparency in the musrenbang and recess period), but in the implementation, the participation in the musrenbang is still considered in the mobilization category 
or in the first level. Meanwhile, during the recess, the participation space is still very limited (limited by $D P R D$ members ) in certain regions with inadequate frequency. Participation through the recess mechanism of board members is still relatively low and is on the first level of participation.

3. Transparency is guaranteed by the leadership culture that is open and the availability of programs that stimulate openness, two-way communication channels between the government and the community and strict application of rewards and punishment. Leadership culture must be formed based on the willingness and commitment to build information disclosure on government and development. It is the commitment in the habituation process that will enhance the culture of transparency. Communication channels in the context of transparency have been built, but government lacks of willingness to use these communication channels. Leaders or staffs who apply transparency should be immediately given adequate rewards, those who deliberately ignore this requirement should be immediately punished in order to create deterrent effect. Factors that guarantee participation are transparency, reduced information distortion, strict awards and punishment system for participating and non-participating communities and sufficient space (time) for community participation. With adequate transparency, adequate rewards and punishment, information clarity and certainty, public participation can be improved in the formulation of public policies (Regional Budget).

\section{SUGGESTIONS}

Regarding to the conclusions of this research, several suggestions or regulation have been proposed for the betterment and enhancement of transparency and community participation in Regional Budget Preparation process.

1. It is considered necessary to facilitate customization from leadership to staffs for better transparency. The habituation process must be done based on the willingness and commitment to build a culture of transparency. The will and commitment need to be demonstrated by senior leaders in front of junior leaders and staffs by strictly applying the legislation that guarantees transparency.

2. The hearing in the form of musrenbang mechanism and the recess period of board members which were still limited to certain parties should be added with new meschanism that facilitate broader participation in the form of public hearing, visitation of local governments and members of the DPRD to their respective constituencies, public consultations, and other alternative mechanisms that provide more space for the community to participate. Visitation from the Regional Government and DPRD members and public hearing should be held to share information regarding general budget policy, budget allocation, and the draft of local regulation on Regional Budget. Such events should be held. However, the one-day musrenbang is not enough to explain all of those necessary information. Public hearings can also be carried out by $D P R D$ members during the third recess to disseminate general budget policies, budget allocation, and draft of local regulations on Regional Budget

3. A transparent culture can be formed through (a) formal processes, i.e. accurate information is conveyed through formal rules and mechanisms, and can be easily accessed (b) Top management's commitment to transparency in the bureaucracy can be enhance through a comprehensive training program, and demonstrations of the how community can participate, including explanation on the communication channels that can be used to report violations. The training will not only teach documentation and reporting competencies, but it will also develop critical thinking and decision-making skills, and stimulate the understanding and commitment to transparency and ethical behavior; (c) better communication with stakeholders. The leadership of an organization should get used to the involvement of stakeholders to look into the organization

\section{REFERENCES}

Creswell, John W. 2002. Research Design Qualitative and Quantitative Approaches, Alih Bahasa Nur Khabibah, KIK Press, Jakarta.

Denhardt, Robert, Denhardt, Robert \& Janet, V. 2006. Public Administration:An Action Overview, Fisth Edition, Op.Cit.

Denhart, Janet, V. dan Robert, B. Denhart, 2007. The New Public Service - Serving, Not Steering, Expanded Edition, M.F. Sharpe, Armonk, New York, London, England.

Denzin, Norman K. \& Lincoln, Yvonna S. 2009. Handbook of Qualitative Research, Pustaka Pelajar, Yogyakarta. Djaha, Ajis Salim Adang. 2012:5. Transparansi Birokrasi, Jurnal Administrasi Publik Volume 11 No. 1 Oktober 2012, ISSN 1412-825X, Kupang.

Dwivedi, O.P. 1988. Introduction: Public Service Responsibility and accountability in Public Service Accountability: A Comparative Perspective, Kumarian Press, Hartford.

Etzioni, Eva \& Halevy. 2009. Demokrasi dan Birokrasi Sebuah Dilema Politik, Op.Cit, hal. 42-44. 
Haryatmoko. 2011. Etika Publik Untuk Integritas Pejabat Publik dan Politisi, Gramedia Pustaka Utama, Jakarta. Henry, Nicholas. 2004. Public Administration and Public Affairs, 9th ed., Pearson Prentice Hall, 2004.

Kumorotmo, 2008. Akuntabilitas Birokrasi Publik: Sketsa Pada Masa Transisi. Pustaka Belajar, Yogyakarta.

Muluk, M.R. Khairul. 2007. Menggungat Partisipasi Publik dalam Pemerintahan Daerah (Sebuah Kajian dengan Pendekatan Berpikir Sistem). Malang: UB.

Oliver, Richard W. 2004. What is Transparency, The McGraw-Hill Companies, Inc.United States America.

Sukardi, Akhmad. 2009. Participatory Governance dalam Pengelolaan Keuangan Daerah. Yogyakarta: LaksBang PRESSindo.

Yin, Robert, K. 1996. Studi Kasus Desain dan Metode, RajaGrafindo, Jakarta. 